\title{
Kontribusi Pragmatik dalam Penerjemahan: Peranan dan Fungsi Praktis
}

\author{
Angga Aminullah Mansur \\ STIBA Invada Cirebon \\ qazkila246@gmail.com
}

\begin{abstract}
Abstrak
Makalah ini memaparkan kontribusi pragmatik secara umum yang meliputi peranan dan fungsi praktis pragmatik dalam penerjemahan. Dari segi peranan, sebagai cabang ilmu linguistik, pragmatik berkontribusi besar sebagai sumber obyek kajian penerjemahan - yang salah satunya adalah tindak tutur. Dalam hal fungsi, pragmatik merupakan alat atau media yang dapat dipergunakan untuk menyelesaikan kendala-kendala pragmatis dalam penerjemahan serta sarana untuk mengasah kompetensi seorang penerjemah dalam menerjemahkan. Dalam makalah ini, dijelaskan pula mengenai kaitan antara pragmatik dan penerjemahan yang dijembatani oleh makna.
\end{abstract}

Kata kunci: pragmatik, makna, kontribusi, penerjemahan

\begin{abstract}
This paper presents pragmatics's contribution to translation: its role and practical function. Based on its role, as one of linguistics branches, pragmatics has immensely contributed to the provision of the abundant objects of translation studies. From its practical function, pragmatics can be employed as an artifact to solve pragmatic constraints found in translation and as a medium for improving translator's competence in translating. This paper also explains the co-relation between pragmatics and translation that is associated by meaning as their linkingbridge.
\end{abstract}

Key words: pragmatics, meaning, contribution, translation

\section{PENDAHULUAN}

Bahasa merupakan sebuah sistem yang memadukan dunia bunyi dan dunia makna. Pada hakikatnya, yang dimaksud dengan bunyi dan makna di sini ialah bunyi dan makna bahasa yang bertemu dalam tiga tataran subsistem bahasa, yakni fonologi, gramatika, dan leksikologi, untuk kemudian membentuk sebuah struktur bahasa. Di luar struktur bahasa inilah terdapat konteks, yakni segala hal atau informasi yang melatarbelakangi berlangsung atau terjadinya wujud bahasa baik dalam bentuk lisan maupun tulisan. Makna dan konteks ini dikaji dalam ranah pragmatik — cabang Linguistik yang mempelajari makna sebagaimana dimaksudkan penutur. 
Fokus utama kajian pragmatik, sebagaimana dikemukakan oleh Yule (1996: 3), ialah makna dan konteks. Makna dipahami sebagai apa yang dimaksudkan oleh penutur dalam konteks tertentu. Sementara itu, konteks berkaitan erat dengan situasi tutur yang meliputi siapa yang sedang berbicara, dimana, kapan, dan dalam situasi apa. Konteks memiliki peranan penting dalam mempengaruhi apa yang hendak disampaikan oleh si penutur.

Berkenaan dengan hal ini, dalam menrjemahkan sebuah satuan lingual, seorang penerjemah perlu memahami konteks yang melingkupi satuan lingual tersebut dengan baik sehingga dapat mengungkap pesan terjemahan dengan baik dan jelas pula. Hal ini menunjukkan bahwa pengetahuan dan kompetensi pragmatik sangat dibutuhkan oleh seorang penerjemah dalam kegiatan penerjemahan.

\section{PEMBAHASAN}

\section{A. Seputar Makna dan Pragmatik}

Istilah pragmatik berawal dari gagasan mengenai 'semiotika bahasa' yang dikemukakan oleh Morris (1938). Menurutnya, ilmu lambang dan tanda bahasa dibagi ke dalam tiga bagian, yakni (1) Sintaktika (Syntactics) yaitu bagian ilmu lambang dan tanda bahasa yang mengkaji relasi formal tanda-tanda (2) Semantika (Semantics) yaitu bagian ilmu lambang dan tanda bahasa yang mengkaji relasi tanda-tanda dengan objeknya, serta (3) Pragmatika (Pragmatics) yaitu bagian ilmu lambang dan tanda bahasa yang mengkaji relasi tanda-tanda dengan penafsirannya. 'Tanda-tanda' di sini dapat kita pahami sebagai 'makna bahasa'.

Dapat kita cermati bahwa dalam kajian lambang dan tanda bahasa tersebut terdapat dua ranah yang seolah-olah sejajar karena sama-sama mengkaji makna namun pada kenyataannya jauh berbeda, yakni antara ranah semantik dengan ranah pragmatik. Sebagaimana diungkapkan Rahardi (2005), perbedaan antara semantik dan pragmatik dapat dilihat dari sedikitnya empat aspek, yaitu (1) kajian pragmatik mengkaji makna bahasa secara eksternal, sementara semantik secara internal (2) sifat makna pragmatik terikat konteks, sedangkan makna semantik bersifat lepas konteks (3) makna semantik bersifat diadik, sementara makna pragmatik bersifat triadik (4) tujuanp pragmatik ialah memahami makna penutur, sementara tujuan semantik ialah makna satuan lingual itu sendiri.

Untuk lebih jelasnya, mari kita tilik beberapa batasan mengenai makna kajian pragmatik yang dikemukakan oleh beberapa pakar. Yule (1996) memandang makna dalam pragmatik sebagai makna kontekstual yakni makna yang dimaksudkan penutur dalam 
konteks tertentu. Dalam pandangannya, makna sebuah tuturan betul-betul dipengaruhi oleh konteks. Konteks ini meliputi siapa yang terlibat dalam tuturan tersebut, dimana tempat berlangsugnya, kapan terjadinya, dan dalam kondisi atau situasi seperti apa. Sejalan dengan apa yang dikemukakan oleh Yule ini, Leech (1983) menyebutkan bahwa makna dalam pragmatik ialah makna yang berhubungan dengan situasi tutur. Oleh karena itu, ia lebih memandang pragmatik secara praktis karena berkenaan dengan makna dan penggunaannya. Keeratan antara makna dengan konteks ia jelaskan lebih jauh dalam teori situasi tutur yang dikemukakannya. Ia mengemukakan bahwa konteks sebuah tuturan merupakan segala pengetahuan akan latar belakang mengenai apa yang sedang dibicarakan yang sama-sama dimilki oleh penutur dan petutur sehingga petutur dapat menafsirkan apa yang disampaikan oleh penutur. Levinson (1983) mengkaitkannya dengan wujud bahasa secara struktural. Ia menyebutkan makna dalam pragmatik sebagai makna kontekstual yang diejawantahkan dalam struktur bahasa.

Mari kita simak dua contoh percakapan berikut ini,

(1) A : "Sudah lama di Solo?"

B : "Baru setengah tahun."

A : "Aslinya mana?"

B : "Bogor."

bandingkan,

(2) A : "Maaass, cepetan dooong!!"

B : "Iya, iya. Sebentar, dikit lagi ini."

A : "Aslinya mana?"

B : "Siip. Ini, Bos.”

Dua percakapan di atas dipayungi oleh konteks tuturan yang berbeda meskipun samasama melibatkan dua penutur dan menuturkan tuturan yang serupa sebagaimana kita lihat pada masing-masing tuturan penutur A yang sama-sama menuturkan pertanyaan "Aslinya mana?" Dalam percakapan pertama, dapat kita bayangkan bahwa percakapan tersebut merupakan obrolan kecil yang mungkin saja berlangsung di tempat umum ketika orang sedang menunggu angkutan atau ketika mengantri dan tidak saling mengenal. Ketika penutur A menanyakan "Aslinya mana?" tanggapan yang timbul dari penutur B ialah "Bogor". Dalam tuturan ini makna pertanyaan “Aslinya mana?” memilki makna menanyakan asal tempat tinggal atau daerah si lawan bicara. Sementara itu, dalam percakapan kedua, tuturan penutur A “Aslinya mana?” ditanggapi dengan jawaban berbeda oleh si lawan bicara "Siip. 
Ini, Bos" Dapat kita cermati bahwa mungkin saja percakapan kedua ini terjadi di tempat fotokopian dan tuturan “Aslinya mana?" tidak dimaksudkan untuk menanyakan asal tempat tinggal si lawan bicara akan tetapi meminta buku asli yang difotokopi. Dengan demikian, dapat kita simpulkan bahwa konteks sangat mempengaruhi makna sebuah tuturan serta menjadi penentu arah dan tujuan akan apa yang dituturkan oleh masing-masing pihak yang terlibat dalam sebuah percakapan.

Demikian jelas bahwa makna dalam pragmatik merupakan makna yang tidak terlepas dari konteks penggunaannya. Makna sebuah satuan lingual dapat diungkap dengan jelas apabila ada pemahaman yang baik mengenai konteks yang melatarbelakangi satuan lingual tersebut. Dalam kegiatan komunikasi sehari-hari, penahaman akan konteks berperan dalam membangun kesepahaman antar pihak yang terlibat dalam aktivitas komunikasi tersebut. Sementara itu, dalam penerjemahan, seorang penerjemah perlu memiliki kepekaan akan konteks yang memayungi sebuah teks yang hendak diterjemahkan. Seorang penerjemah harus betul-betul jeli dalam memaknai teks dan memperhatikan konteks yang melingkupinya.

\section{B. Makna Pragmatik dalam Penerjemahan}

Kegiatan penerjemahan tidak akan pernah terlepas dari teori dan aspek kebahasaan, termasuk di dalamnya aspek pragmatik, karena penerjemahan merupakan aktivitas yang dilakukan pada bahasa. Catford (1965) mengungkapkan penerjemahan sebagai sebuah operasi yang dilakukan atas bahasa yang mengacu pada proses penggantian materi teks suatu bahasa tertentu dengan materi teks bahasa yang lain. Untuk menunjang proses tersebut, diperlukanlah teori-teori kebahasaan atau linguistik umum.

Perlu kita pahami terlebih dulu bahwa wujud bahasa yang dimaksudkan dalam batasan tersebut ialah teks. Di dalam teks terdapat pesan atau makna yang hendak disampaikan dan berkenaan dengan konteks. Halliday dan Hassan (1985) mengemukakan bahwa pemahaman akan bahasa terletak pada kajian sebuah teks dan konteks sebagai aspeknya. Apa yang terkandung dalam teks tidak hanya mengacu pada apa yang dituliskan atau diucapkan saja tetapi juga apa yang melingkupinya secara keseluruhan. Sebagai contoh misalnya, dalam memahami bahasa dalam kaitannya dengan struktur sosial, pemahaman akan konteks sosial digunakannya bahasa tersebut menjadi sebuah tuntutan. Sejalan dengan hal ini, Baker (1992) menandaskan bahwa pemahaman akan teks sumber itu lebih dari apa yang diacukan secara tertulis. Sebuah teks akan dapat benar-benar dipahami apabaila dikaitkan dengan 
konteksnya. Konteks dapat berupa konteks situasi, konteks budaya, konteks intratekstual, dan konteks inertekstual.

Aspek makna dalam penerjemahan pragmatik berkaitan dengan dua tataran maknamakna sebagai esensi dari apa yang diucapkan dengan makna sebagai esensi dari apa yang dimaksudkan. Anggapannya kurang lebih sama dengan apa yang kita kenal sebagai makna tersurat dan makna tersirat. Pragmatik sendiri lebih cenderung berada dalam wilayah makna tersirat dari apa yang dituturkan berbeda halnya dengan makna Semantik yang berada dalam wilayah makna tersurat sebagaimana diucapkan atau dituliskan dalam satuan lingual. Untuk lebih jelasnya, marilah kita cermati pembagian makna tuturan sebagaimana dikemukakan oleh Grice (1989):

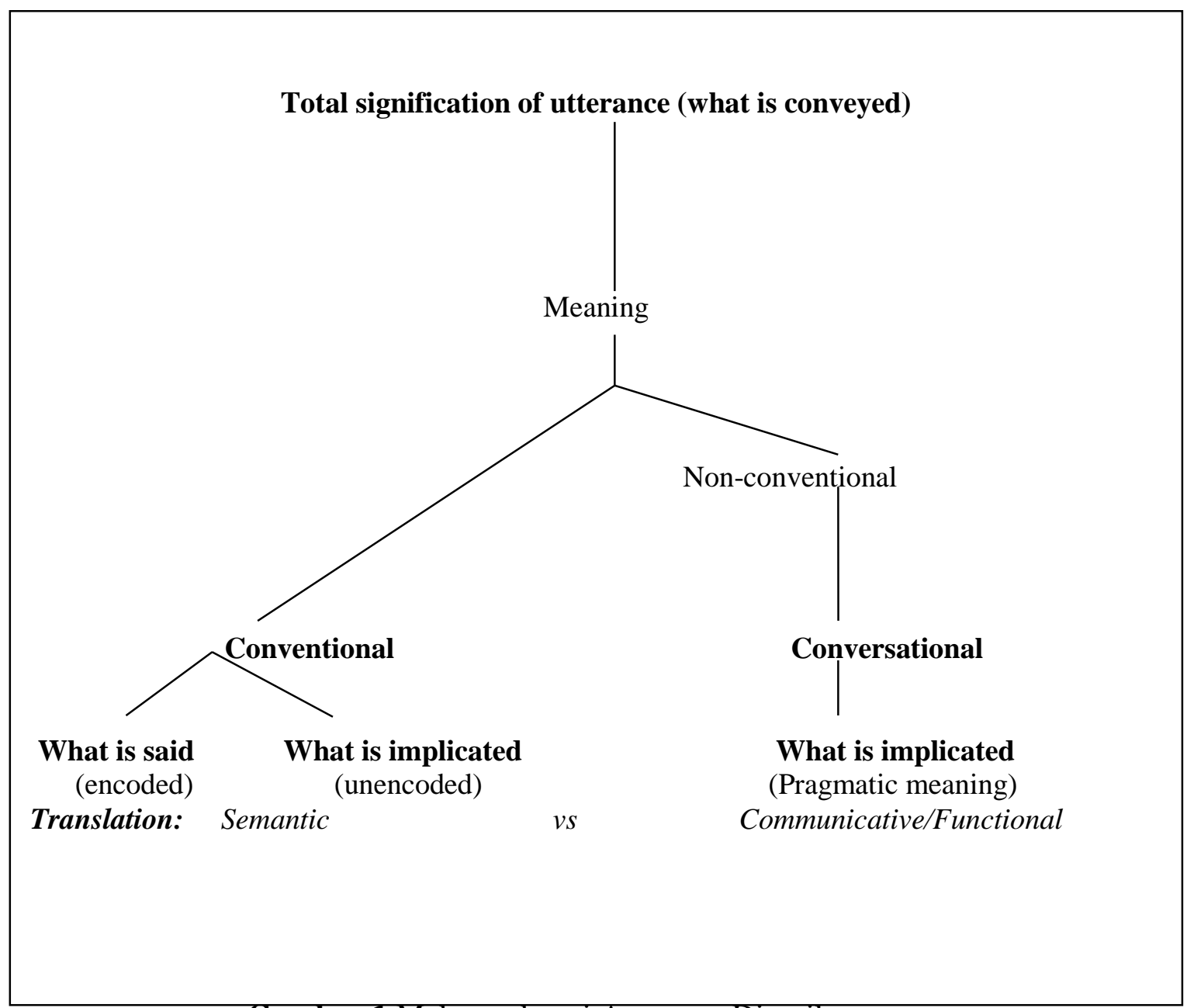

Gambar 1 Makna sebagai Apa yang Diperikan

Berbeda halnya dengan makna dalam semantik yang bersifat konvensional dan menjadi tujuan dari Penerjemahan Semantis, makna pragmatik bersifat konversasional (diwujudkan dalam percakapan) dan menjadi tujuan dari penerjemahan komunikatif / 
fungsional. Selain itu, makna pragmatik memilki peranan penting dalam menentukan fungsi sebuah teks atau tuturan. Oleh karenanya, seorang penerjemah dituntut untuk memiliki kompetensi yang baik dalam mengidentifikasi makna tersirat dari sebuah tuturan. Ia harus bisa mengetahui apa maksud dan tujuan dari si penulis, kenapa ia lebih memilih bentuk struktur yang digunakan, dan harus dapat mengemukakan kembali secara akurat maksud atau makna tersirat tersebut dalam BSa. Untuk lebih jelasnya kedua jenis penerjemahan ini akan dibahas dalam bagian selanjutnya.

\section{Aktualisasi Pragmatik dalam Penerjemahan: Peranan dan Fungsi}

Dalam kaitannya dengan penerjemahan, wujud bahasa atau teks dalam pragmatik dipandang sebagai performansi yang diaktualisasikan dalam wujud tindak bahasa yang kita kenal sebagai tindak tutur (speech act). Tatarannya pun tidak berada pada tataran kata melainkan pada tataran kalimat dalam wujud tuturan sebagaimana dituturkan oleh si penutur. Untuk itu, penerjemahannya akan menitikberatkan pada tataran tindak tutur (speech act) sebagai tindak berbahasa dibanding pada tataran kata (Austin, 1962; Searle, 1971; Bach dan Harnish, 1984; Robinson, 2008). Gambarannya dapat kita cermati dalam skema sebagaimana diungkaapkan oleh Kitis (2009) berikut ini:

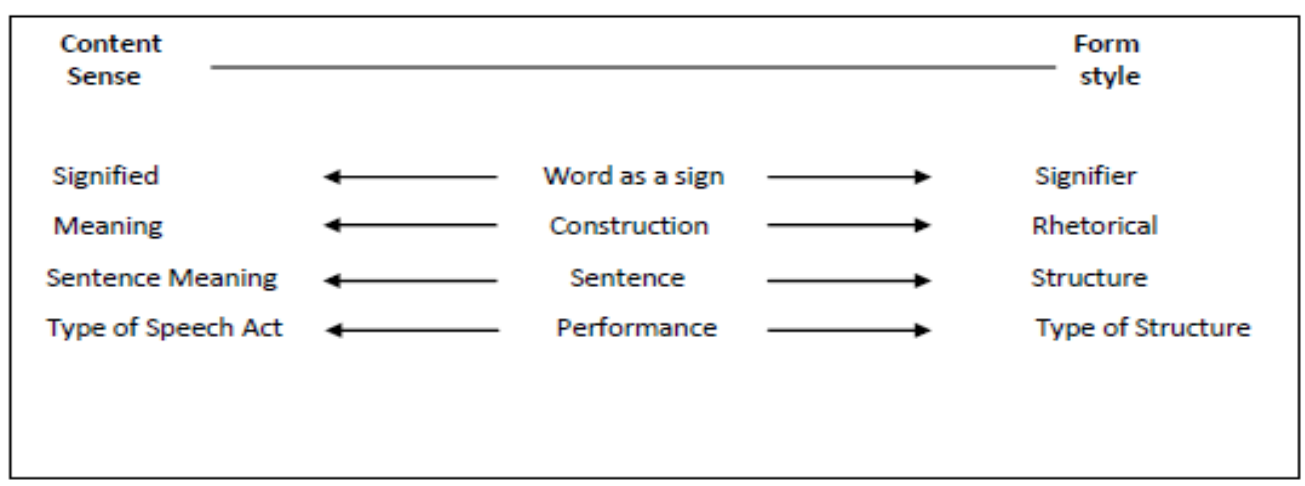

Gambar 2 Option for the unit of translation

Dapat dijelaskan di sini bahwa unit penerjemahan diapit oleh bentuk di sebelah kanan dan nilai fungsionalnya di sebelah kiri. Pragmatik sebagai performansi merupakan unit penerjemahan yang menduduki tataran paling bawah yang diwujudkan dalam jenis struktur tertentu dengan nilai fungsional tindak tutur tertentu pula. Tataran inilah yang menjadi fokus perhatian penerjemahan dalam pragmatik. 
Setelah mengetahui unit penerjemahan dalam penerjemahan pragmatik, kita akan mengidentifikasi pendekatan penerjemahan apa yang paling tepat untuk diterapkan dalam menerjemahkan unit penerjemahan ini. Sekilas telah kita ketahui dalam bagian terdahulu mengenai makna pragmatik dalam penerjemahan, bahwa makna pragmatik berada dalam wilayah pendekatan penerjemahan komunikatif / fungsional yang jelas-jelas berlawanan dengan pendekatan penerjemahan semantik. Hal ini dapat kita lihat dari dikotomi penerjemahan yang dijelaskan oleh Kitis (2009) pada gambar berikut ini:

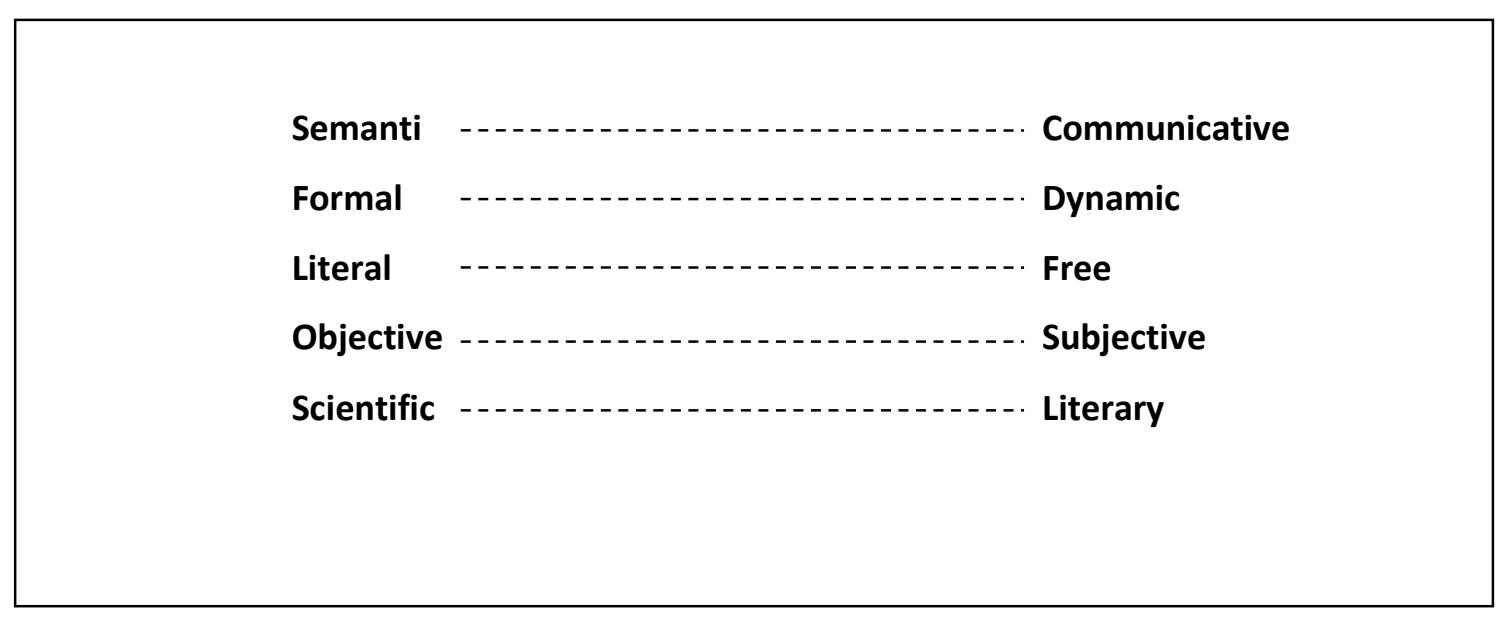

Gambar 3 Dichotomies in Translation

Merangkum dari gagasan beberapa pakar penerjemahan (Nida dan Taber, 1969; Newmark, 1981), Kitis (2009) mengemukakan pembagian pendekatan penerjemahan sebagai dua kutub yang berlawanan. Ia mencermati bahwa kutub sebelah kiri bersifat lebih statis dibandingkan dengan kutub sebelah kanan yang bersifat dinamis. Penerjemahan semantik menitikberatkan pada unit leksikal, frasa, dan struktur kalimat pada BSu dengan memberikan perhatian khusus pada makna leksikal dan semantisnya. Sementara itu, penerjemahan komunikatif lebih menitikberatkan pada upaya untuk menciptakan efek atau pengaruh teks yang sama ke dalam BSa sebagaimana ditimbulkan oleh teks BSu-nya. Begitu pula pada penerjemahan formal, pendekatan ini lebih menitikberatkan pada struktur lahir BSu. Sementara itu, penerjemahan dinamis lebih menitikberatkan pada upaya untuk membangun tanggapan yang sama dari kedua golongan pembaca baik sumber maupun sasaran atas apa yang dialihkan.

Implementasi dari pendekatan penerjemahan di atas dapat kita cermati dalam penerjemahan tindak tutur. Dalam menerjemahkan tindak tutur, penerjemah memiliki misi 
untuk menerjemahkan sebuah tindakan dan pengaruh dari tindak tutur tersebut. Kitis (2009) menyebutkan bahwa setiap tuturan merepresentasi tiga aspek tindak tutur dengan daya tertentu dan penerjemahanya dilakukan dengan menggunakan pendekatan penerjemahan komunikatif. Relasi ini dapat kita lihat dari gambar berikut ini:

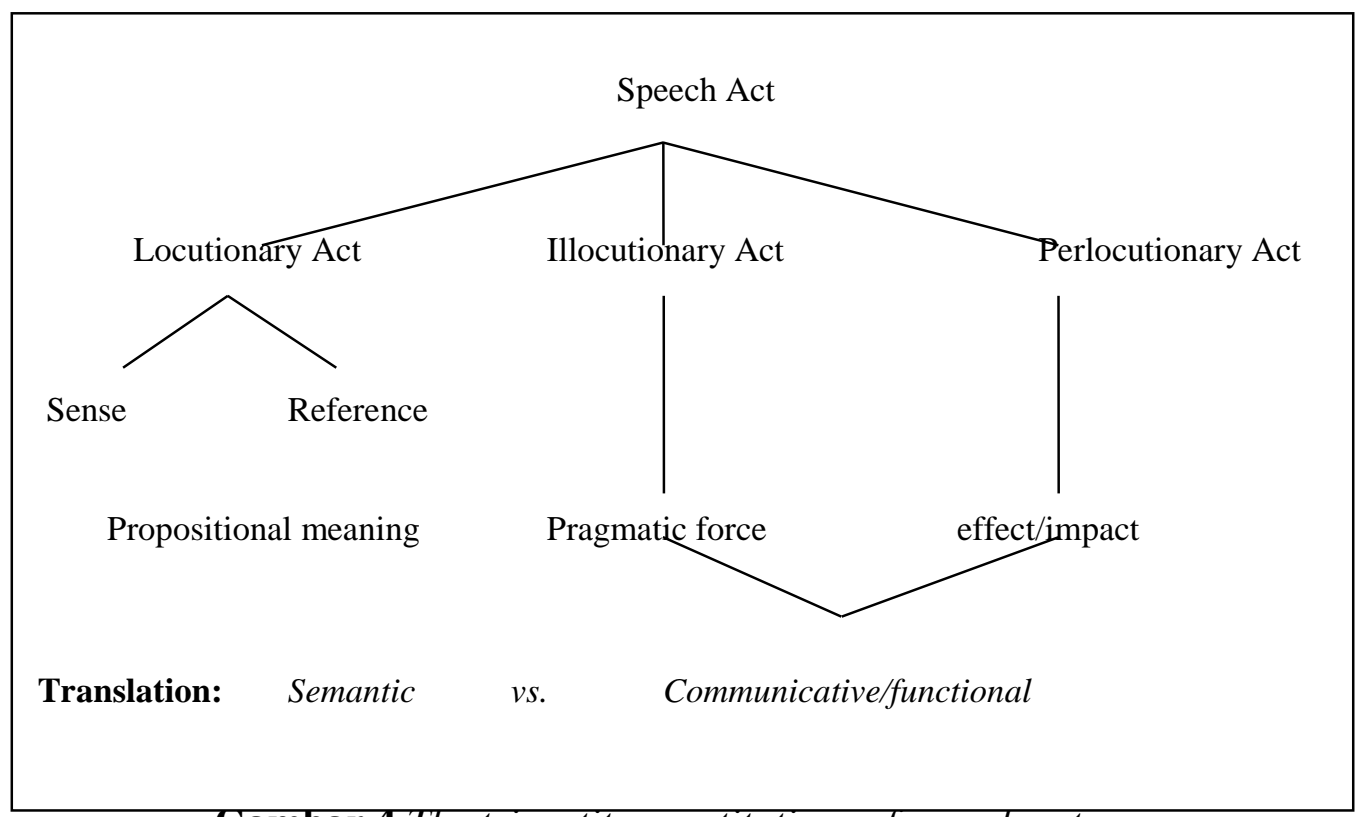

Gambar 4The tripartite constitutions of speech act

Dapat kita cermati dari relasi di atas bahwa penerjemahan komunikatif menitikberatkan pada tindak ilokusi dan perlokusi sementara penerjemahan semantik fokus pada tindak lokusi. Aspek makna pada tindak lokusi berorientasi pada makna tuturan sebagai apa yang diucapkan tanpa memperhatikan fungsi yang menaungi makna tersebut. Sementara itu, aspek makna pada tindak ilokusi dan perlokusi berorientasi pada daya pragmatik yang terkandung dalam tindak ilokusi dan efek yang ditimbulkan dari tindak ilokusi tersebut dalam tindak perlokusi. Aspek-aspek lain seperti tanda baca, struktur kalimat, modalitas, atau penanda wacana juga hal yang perlu dperhatikan terkait makna ilokusi dan perlokusi ini. Untuk itu, Robinson (2003) menyebutkan bahwa pengetahuan dan kepekaan pragmatis dapat mempertajam keahlian seorang penerjemah. Lalu pertanyaan yang muncul ialah 'Bagaimana tindak tutur itu diterjemahkan?' Honig dan Kusmaul dalam Fawcet (1997), sehubungan dengan penerjemahan tindak ilokusi, mengemukakan bahwa hasil terjemahan yang baik ialah terjemahan yang memiliki daya ilokusi yang sama seperti pada Bsu-nya. Artinya, ketika menerjemahkan sebuah tindak tutur, seorang penerjemah harus betul-betul 
mempertahankan daya ilokusi yang tertuang dalam BSu dan menghindari pergeseran tindak ilokusi ketika diterjemahkan dalam BSa-nya.

Obyek pragmatik seperti halnya tindak tutur ini bukanlah unit bahasa yang mudah dan dapat diterjemahkan begitu saja. Fitur-fitur pragmatis sangat berguna dan dapat dijadikan sebagai alat bantu dalam mengupayakan pengalihan pesan atau makna sebagaimana diharapkan. Mengadopsi gagasan Grice, Baker (1993) mengemukakan beberapa aspek atau faktor yang betul-betul harus diperhatikan dalam menerjemahkan makna tersirat sebuah tuturan, yaitu:

(1) Makna tersurat dari kata-kata atau struktur kalimat yang digunakan beserta segala referensi yang tertera melingkup kata-kata atau struktur kalimat tersebut

(2) Prinsip Kerjasama berikut semua Maksimnya

(3) Konteks yang melingkupi tuturan tersebut, baik konteks linguistik maupun yang lainnya

(4) Latar belakang pengetahuan pendukung lainnya

(5) Relevansi fakta yang sama-sama dipahami oleh masing-masing partisipan

Dari poin-poin di atas, dapat kita pastikan bahwa seorang penerjemah perlu memiliki dasar pengetahuan mengenai pragmatik. Dasar pengetahuan ini berkaitan erat dengan unit penerjemahan dalam tataran pragmatik. Teori-teori dan gagasan-gagasan mengenai tindak tutur dan implikatur diperlukan dalam mengungkap pesan terjemahan sebagaimana betulbetul dimaksudkan. Pemahaman akan konteks yang melingkupi unit penerjemahan pun perlu diperhatikan dalam membantu pengungkapan makna atau pesan terjemahan.

Pragmatik memberikan sumbangsih yang sangat besar dalam dunia penerjemahan. Selain sebagai obyek kajian penerjemahan, pragmatik juga merupakan pemberi solusi atas kendala-kendala pragmatis yang muncul dalam penerjemahan.

\section{KESIMPULAN}

Dapat kita telusuri bahwa jembatan penghubung antara pragmatik dan dunia penerjemahan adalah makna. Makna di sini adalah makna pragmatik yakni makna sebagaimana dimaksudkan penutur bukan semantis sebagai apa yang diucapkan atau dituliskan penutur. Sifatnya tersirat (implisit) bukan tersurat (eksplisit) serta wujudnya konversasional bukan konvensional. 
Pragmatik memberikan kontribusi besar dalam penerjemahan. Kontribusi tersebut dapat dilihat dari dua aspek, yakni peranan dan fungsi praktis. Pragmatik merupakan sumber kajian bagi penerjemahan. Fitur-fitur pragmatik seperti tindak tutur, implikatur, prinsip kerjasama, kesantunan, dan peranggapan merupakan obyek kajian yang melimpah yang menarik untuk dikaji. Pendekatan yang diterapkan bukan penerjemahan semantis melainkan penerjemahan komunikatif.

Dari aspek fungsi praktis, pragmatik sangat berguna bagi seorang penerjemah dalam menghadapi kendala-kendala pragmatis ketika menerjemahkan. Sebagai contoh, ketika dihadapkan pada penerjemahan tindak tutur, banyak hal yang harus ia perhatikan dan pertimbangkan untuk dapat mengungkap pesan dari BSu ke dalam BSa tanpa mengubah daya pragmatisnya. Kepekaan terhadap fitur-fitur linguistik atau pragmatik sangat dibutuhkan dan hal tersebut akan mengasah keterampilan penerjemah dalam menerjemahkan. Semakin banyak pengetahuan pragmatis seorang penerjemah, maka semakin peka pula dirinya dalam menerjemahkan. Semakin peka seorang penerjemah, maka akan semakin mudah baginya untuk mengungkap makna atau pesan dari obyek penerjemahan yang ia terjemahkan. Dengan kata lain, pragmatik mempunyai kontribusi praktis sebagai sarana untuk dapat memperjelas pengungkapan makna atau pesan terjemahan.

\section{REFERENSI}

Austin, J.L. 1980. How to Do Things with Words. Cambridge: MA: Harvard University Press.

Bach, K and R. Harnish. 1984. Linguistic Communication and Speech Acts. MTT Press.

Baker, Mona. 1992. In Other Words. London \& New York: Routledge.

Catford, J.C. 1965. A Linguistics Theory of Translation. London: Oxford University Press.

Kitiz, Eliza. 2009. The Pragmatic Infrastructure of Translation dalam Traducao e Comunicacao. no. 18. Hal.63-85 diunduh dari http://ipade@unianhanguera.edu.bra pdf pada 13 September 2013.

Fawcet, P. 1997. Translation and Language. U.K: St. Jerome Publishing.

Grice, P.H. Studies in the Way of Words. Cambridge, MA: Cambridge University Press. 
Halliday, M.A.K and Hassan, R. 1989. Language, Context, and Text: Aspects of Language in A Social-Semiotic Perspective. Victoria: Brown Prior Anderson Pty Ltd.

Leech, Geoffrey N. 1983. Pragmatics. London: Cambridge University Press.

Levinson, S.C. 1983. Pragmatics. Cambridge: Cambridge University Press.

Newmark, P. 1981. Approaches to Translation. New York: Pergamon Press.

Nida, E.A. and Taber, C.R. 1982. The Theory and Practice of Translations. Leiden: E.J. Brill.

Rahardi, K. 2005. Kesantunan Imperatif Bahasa Indonesia. Jakarta: Penerbit Erlangga.

Robinson, D. 2003. Performative Linguistics: Speaking and Translating as Doing Things with Words. New York \& London: Routledge.

Searle, John R. 1969. Speech Act An Essay in the Philosophy of Language.

Cambridge: Cambridge University Press.

Yule, George. 1996. Pragmatics. Oxford: Oxford University Press. 